\title{
Measuring the Effectiveness of Gross Split System in Production Sharing Contract as Form of Nation Energy Sovereignty
}

\author{
Yudho Taruno Muryanto \\ Faculty of Law \\ Universitas Sebelas Maret \\ Solo, Indonesia \\ yudho_fhuns@yahoo.com
}

\begin{abstract}
A fundamental philosophy of sharing contract states that the ownership of natural resource is in the government authority until the point of turning over, controlling operational management under country control, capital and risk entirely is the responsible of the contractor. Gross Split mechanism in Production sharing Contract creates several issues such as, first the law impact on the regulation of implementation particularly those relating to production sharing contract (PSC). Second, the uncertainty of field commerciality counting either relating to economic value achievement or the economy aspect which cannot be achieved. Third, the goods and operational land post activity. Fourth, the settlement and position of contractor in oil contract in Gross Split mechanism which is inferior.
\end{abstract}

To solve the problem above, it needs strategic steps done, such as first, do synchronization and harmonization for law product relating to management in oil field in order that there is law certainty, second, it needs to review the share or percentage between contractor and government in Gross Split contract with many considerations of business worthiness, and position of the sides in contract sharing by attending technology and capital, and risk of the sides involved in PSC Gross Split in order that in fulfilling proportionality principle in the sharing contract is suitable with rule in the regulation No. 22 in 2001 and other implementation rules

Keywords-effectiveness of Gross Split, Production Sharing Contract, nation sovereignty

\section{INTRODUCTION}

Sovereignty of natural resource management in the soil of Indonesia is based on the basic law 1945 especially in the article of 33 verse (2) and (3) states that :

Ayat (2) : Cabang-cabang produksi yang penting bagi Negara dan yang menguasi hajat hidup orang banyak dikuaasai oleh Negara.

Ayat (3) : Bumi, air, dan kekayaan alam yang terkandung didalamnya dikuasi oleh Negara dan dipergunakan untuk sebesar-bsearnya kemakmuran rakyat.

The state authority and management of the natural resource is based on the constitution statement is in the authority of the country and used for people welfare. Authority is translated as settlement is in the country. The state authority is concept of organization containing authority, rule, and supervise the management or ownership of the mine, which is oil and gasoline [1]. The control and management of natural resource (oil and gasoline) cannot be fully done by the government. Principally, the scope of control by the government includes manage and administer and turn over the management of the natural resource (oil and gasoline) to other side, but the government has sovereignty on the mine [2].

Principally, production sharing contract is based on principles relating to sides in the contract which the law relationship is determined by the sides involved relating to the disobedience and law responsibility in the contract.

A.PSC is based on contractual principles for relationship between the parties (HS \& IOC) with regards to exploration and production. The rights and obligations for the parties are determined under the contract itself, so that the relationship would legally be equal and any sort of breach raises the issue of contractual and legal liability.[3]

Term of production sharing contract, before the existence of law No. 22 in 2001 about oil and gasoline, has been regulated by law No. 8 in 1971 about Pertamina especially article 12 verse (2). In production sharing contract, there is mechanism of cost replacement issued by contractor knows as "Cost Recovery". Cost Recovery system, for several sides, reflects profit sharing in head activity of oil and gasoline. In this case, country as the owner of the resource feel lose with the scheme of the contract.

Cost Recovery scheme in production sharing contract (PSC) of the result of the production and taken operational cost can result in the accepted result by the state as the owner of the resource which is reduced and smaller that part accepted by the contractor. Sani saidu states that Indonesia in production sharing contract does not provide royalty payment, therefore the first allocation is for cost recovery limited to $80 \%$.

The Indonesian contracts did not provide for any royalty payments therefore the first allocation is cost recovery which is limited to $80 \%$ and it amaounted to $\$ 400$, thus the remaining $\$ 100$ is profit oil and is to be share $72 \%$ against $28 \%$ in favour of government. Therefore the government gets $\$ 72$ while the contractor gets \$28”.[4] 
Sani saidu statement is supported by Parulisn Sihotang stating that:

" Changes in PSCs term and condition over the last 30 years have done more harm than good for developing an accountable and transparent government led management led management of Indoensian petroleum industry[5].

Based on the condition, the writer infers that production sharing contract scheme (PSC) using Cost Recovery system is regarded as not profitable for the government of Indonesia, so it emerges production sharing contract (PSC) option using Gross Split. The production sharing contract (PSC) uses Gros Split scheme on the production gross payment without mechanism of operational cost replacement.

\section{DISCUSSION}

The natural resource management in oil and gasoline, ministry of energy and human resources, Arcandra, states nowadays Indonesia has proved reserve of oil as 3.3 billion barrel. With assumption of constant production 800.000 a day without new inventory, then in 11 to 12 year in the future Indonesia cannot produce oil anymore. "Tapi ini mungkin tidak 11-12 tahun kedepan, karena produksi akan turun. Tahun depan mungkin turun menjadi 700.000 (bph) dan seterusnya," he said. Factor of technology and new inventory, said Arcandra, is a key of oil production sustainability in Indonesia. The proved reserve of oil in Indonesia achieving 3.3 billion barrel is not plenty. Comparing to world oil reserve, Indonesia has only 0.2 percent. Besides, Reserve Replacement Ratio (RRR) Indonesia is also low[6].

Based on the explanation above, relating to natural resources management in Indonesia especially oil and gasoline, the statement of vice ministry of energy and human resource about "factor teknologi dan temuan cadangan baru (technology factor and new reserve inventory)" is main issue of the system and mechanism applied in oil and gasoline. Most natural resource of oil and gasoline is managed by foreign contractor. The management of oil and gasoline in law No. 22 in 2001 about oil and gasoline still uses sharing cooperation contract, the main factor is that technology and capital. Business of oil and gasoline needs high finance and technology, so sharing concept and cooperation is urgent in the management of oil and gasoline sector. It is different from mechanism of other natural resource lime mining and mineral charcoal referring to law No. 9 in 2004 about Mineral and charcoal using allowance concept (management allowance) in which authority and control is in the government.

Mechanism of oil and gasoline management is based on sharing cooperation contract concept between contractor and the government as the owner of the resource. Ideally they have similar or balanced position in law. The relationship among sides involved in oil and gasoline management is based on private relationship. The writer gets two crucial issues concerning the mechanism of oil and gasoline management using Gross Split system, which the law certainty of Gross Split system in PSC contract and proportionality principle in PSC uses Gross Split system.

Basically, regulation of production sharing contract using Gross Split mechanism is law No. 22 in 2001 about oil and gasoline with regulation of ministry of energy and human resource No. 8 in 2017 about contract of sharing Gross Split containing three basic thing as follow[7]:

1. The ownership of the natural resource is the government until turning over.

2. Controlling operational management is by special work unit of oil and gasoline.

3. Capital and risk is the responsibility of the contractor.

The other regulation in the sharing contract using Gross Split has at least 17 main item determined in the law No. 22 in 2001 about oil and gasoline.

The implementation of sharing contract using Gross Split still has several issues, those are: first impact on law especially the regulation and other regulation above them. In article 56 of the government regulation No. 35 in 2004 about enterprise of oil and gasoline (PP No. 35 in 2004) states that:

(1) Pengaturan biaya investasi dan operasi dari kontrak bagi hasil wajib mendapatkan persetujuan dari Badan Pelaksana.

(2) Kontraktor mendapatkan kembali biaya-biaya yang telah dikeluarkan untuk melakukan eksplorasi dan eksploitasi sebgaimana dimaksud dalam ayat (1)."

The article explains that in conducting mining activity of oil and gasoline, the sharing contract mechanism (either Net or Gross) along with the production sharing, the government replace cost issued by the contractor relating to production and exploitation. It means that government regulation No. 35 in 2004 about mining activity of oil and gasoline uses Cost Recovery system. Based on the above explanation, the implementation of Gross Split system (without Cost Recovery) has no law base. In fact, the regulation of law No. 12 in 2011 about forming regulation, states that law product of ministry regulation should not oppose regulation above them. Therefore, regulation about Gross Split has to adapt the regulation above it, or it can be said that before applying scheme of Gross Split there must be revision of the government regulation. Second, the regulation about field commercialization counting both economy value achievement and opposite regulated in article 7 of energy and human resource ministry regulation No. 8 in 2017. It is not profitable for the contractor, due to the uncertainty in determining a condition in the contract of mining of oil and gasoline using mechanism of Gross Split economically and the ministry having authority to determine whether the condition of oil and gasoline contract. It is not profitable for the contractor and the policy maker in the contract is in the government represented by energy and human resource ministry.

Third, the use of goods and land post mining contract of oil and gasoline is in accordance with regulation of article 21 of ministry regulation No. 08 in 2017 about sharing contract of Gross Split stated that tools used directly in the mining contract of oil and gasoline belong to the state[8]. The condition above is not profitable or not balanced and proportional. It is due to the mechanism of Gross Split does not state operational cost issued in mining contract (Cost recovery). Of the business aspect, it is not profitable for the contractor.

The fourth issue, the position of the contractor within the mining contract of oil and gasoline in Gross Split mechanism tends to be inferior in the scheme of sharing contract. Ideally, 
in contractual relation position of sides is balanced and proportional. Remember the sharing contract of PSC is based on contractual relation, (private) not based on authority relation like in the concept of managing mineral and charcoal.

The position of sides in sharing contract using Gross Split scheme attends rules in the contract and business. In business view, the attractiveness of contractor in PSC contract is the mechanism of operational cost replacement issued by contractor. Concept of mining activity of oil and gasoline is based on aspect "technology and capital". The basic question is who own the technology in PSC contract activity. The both aspects are owned by investor (contractor).

Thus, the law certainty and position of sides which is proportional in the sharing contract using Gross Split mechanism can answer the challenge in investment climate in Indonesia especially in mining management, particularly oil and gasoline. Several consideration of the investor or contractor to invest in a country stated by Konaito et al I that investment decision in mining is determined by mining potentials[9]:

“ (geological potential) politic stability, mineral law (mineral ownership, security of tenture, exploration/mining term, right to transfer oenership), fiscal regime and other factor (provition related management control, enviormental obligations, obligation to workers, market the rigt to use mineral right as collateral, confidentiality of data, and diseputesetlement mechanism)"

\section{CONCLUSION}

Based on the problem above, it needs effort and strategic steps by the government particularly ministry of energy and human resources are: relating to the law issue, it needs synchronization and harmonization on the law product concerning to management of oil and gasoline, especially PSC with mechanism of Gross Split. Synchronization and harmonization are done vertically and horizontally, so issues relating to law product regulating mine in the contract PSC Gross Split can be slowly solved and provide law certainty for sides involved. The efficiency of the application of PSC contract using Gross Split mechanism needs to be reviewed in case of sharing or percentage between contractor and government with many consideration of aspect such as business worthiness, technology and capital, and risk for the sides involved in PSC Gross Split contract. It is conducted to fulfil proportionality principle in sharing contract based on the regulation of law No. 22 in 2001 and other rule of implementation.

\section{REFERENCES}

[1] A. Saleng, Hukum Pertambangan. Jakarta: Sinar Grafika, 2004.

[2] A. Sutedi, Hukum Pertambangan. Jakarta: Sinar Grafika, 2011.

[3] Z. A. A. Ghadas, "Types and Features of International Protelium Contrac," South east asia J. Contemp. business, Econ. law, vol. 4, no. 3 .

[4] S. Saidu, "A Comparative Analysis of Production Sharing Contract of selected Develeping Countries : Nigeria, Indoensia, Malaysia, and Equatorial Guinea," J. Financ. Account., vol. 2, no. 2, p. 39, 2014.

[5] P. Shihotang, "A longitudinal Analysis of Indonesian Production Sharing Contract (PSC)," Quest. Econ. Accountability, J. Winners, vol. 4, no. 2, p. 109, 2003.

[6] "No Title." [Online]. Available: https://www.esdm.go.id/id/mediacenter/arsip-berita/ini-angka-cadangan-migas-indonesia-dan-carameningkatkannya. [Accessed: 28-Jul-2018].

[7] Pasal 56 Peraturan Pemerintah Nomor 35 Tahun 2004 Tentang Kegiatan Usaha Hulu minyak dan gas bumi. .

[8] Pasal 21 Peraturan Menteri Nomor 08 Tahun 2017 Tentang Kontark Bagi Hasil Gross Split. .

[9] Kohnaito and E. All, "Mineral Project in ascan Countries, Geologi, regulation, Fiscal regime and the Enviromenment," Resour. policy, vol. 24, no. April, pp. 87-89, 1998. 